\title{
Lixboa revisitada ou o império retornado: a mito-poética da Mensagem (e uma saudade lusíada) n'As naus de Lobo Antunes
}

\author{
Lixbon revisited or the returned empire: the mythopoetic of Mensagem \\ (and a miss of lusiads) in As Naus by Lobo Antunes
}

\author{
EDVALDO A. BERGAMO \\ Universidade de Brasília \\ Ana Clara Magalhães de Medeiros \\ Instituto Federal de Educação, Ciência e Tecnologia de Goiás
}

27

\begin{abstract}
Resumo: A experiência histórica portuguesa pós-1974 propiciou a difusão de romances de notável arrojo ético-estético. As naus (1988), de António Lobo Antunes, é prosa que remete à tradição literária enformadora da cultura lusa, em que Os Lusíadas, de Camões, e a Mensagem, de Pessoa, são pilares para o estabelecimento de um grande diálogo mito-poético. Aliando mito e poesia, como propõe o teórico Northrop Frye, à noção de saudade, como traço português inerente (conforme Eduardo Lourenço e Teixeira de Pascoaes), este artigo propõe um estudo comparado do romance de Lobo Antunes especialmente à Mensagem (1934): um encadeamento que impele a revisitação ao icônico épico de Camões. Recorrendo-se, ainda, aos conceitos de romance histórico, de György Lukács, e de dialogismo, de Mikhail Bakhtin, o trabalho amplifica discussões suscitadas pelo romance em causa: a tensão entre a história hegemônica e a vida comum, a tradição literária e os impasses político-sociais do século XX.
\end{abstract}

Palavras-chave: Lobo Antunes; Pessoa; Camões; Romance histórico português contemporâneo

\begin{abstract}
The Portuguese experience after 1974 propitiated a diffusion of notable boldness ethic-aesthetic novels. As Naus (1998), written by Lobo Antunes, is a prose that remit to the literary tradition of the Portuguese cultural form, in which Lusiadas, by Camões, and Mensagem, by Pessoa, are the pillars to the establishment of a major myth-poetic dialogue. Combining myth and poetry, as proposes the theorist Frye, the notion of saudade [yearning], as an inerent Portuguese feature (according to Lourenço and Pascoaes), we propose a comparated study in the romance of Antunes, especially to the Mensagem (1934): a chaining that drives the revisitation to the iconic Epic of Camões. Recurring to the concepts of the historical novel, by Lukács, and the dialogic of Bakhtin, this document amplifies the discussions instilled by the novel in cause: the tension between hegemoniacal history and common life, the literary tradition and the political stalemates of the XX century.
\end{abstract}

Keywords: Lobo Antunes; Pessoa; Camões; Portuguese Historical Contemporary Novel

António Lobo Antunes é, ao lado de José Saramago, Lídia Jorge e Mário Cláudio, dentre outros, componente do proeminente grupo de ficcionistas lusófonos que, após a Revolução dos Cravos (1974), inscrevem-se numa tradição de romances históricos dotados de profunda consciência ética, além de notável valor estético. Com a responsabilidade de recontar - de maneira menos monológica e unilateral - a narrativa de apogeu e declínio de um império colonial longevo, as implicações identitárias de um país europeu marginal e de suas empreitadas colonizadoras para além-mar, o romance lusitano contemporâneo ganha lugar no grande tempo da literatura mundial com obras de força. Levantado do Chão (1980), A jangada de pedra (1986) - ambos de José Saramago, A peregrinação de Barnabé das Índias (1998), de Mário Cláudio, e $O$ vento assobiando nas gruas (2002), de Lídia Jorge, são exemplos de escritos que se unem à publicação possivelmente mais engenhosa 
de Lobo Antunes, As naus (1988), para recontar e redimensionar criticamente os rumos da audaciosa, porém contraditória, história portuguesa.

Justamente este último romance é que movimenta a discussão proposta aqui: As naus deflagram o inviável retorno à Lisboa (daqui para frente, Lixboa, como prefere nosso narrador) dos dias de hoje por figuras eloquentes da colonização ultramarina, tais como Diogo Cão, Pedro Álvares Cabral, Vasco da Gama, Manuel de Sousa de Sepúlveda. Além de importantes nomes da literatura moderna ascendente, a exemplo de Luís de Camões e Miguel de Cervantes - todos misturados a personas da vida ordinária, habitantes de uma Lixboa povoada por retornados de África ou de cercanias de Portugal.

O título do romance, a rememoração de grandes personagens da expansão marítima, a evocação de uma cultura nacional baseada na experiência de partida e chegada já seriam suficientes para conduzir o leitor a uma correlação com o marco da literatura nauta moderna: $O s$ lusíadas (1572), de Luís de Camões. Poema épico também publicado, vale ressaltar, em momento de duvidosa e inglória condição da nacionalidade para Portugal - durante o domínio espanhol sobre o reino lusitano. Aqui, estabeleceremos tal comparatismo, mas por viés distinto. Nosso ponto central de discussão será a ideia de saudade - conforme entendida por Eduardo Lourenço, em Portugal como Destino seguido de Mitologia da Saudade (1999), e Teixeira de Pascoaes, de Os poetas lusíadas, 1987 -, que funciona como elemento estruturante de todo o romance. A eleição da saudade não é arbitrária, sobretudo se consideramos que a obra em questão debate vivamente a problemática dos retornados do mundo colonial esfacelado para a nostálgica Lixboa: a caótica metrópole de um império em escombros.

O caminho para se pensar estas duas obras polares - de Lobo Antunes e Camões - será outro pilar da cultura portuguesa: Mensagem (1934), de Fernando Pessoa. Uma vez mais, momento de crise histórica: escrito à luz do apogeu salazarista, o poema é um canto epizante, mas também lírico-elegíaco, que acompanha o desfraldar de um processo histórico condenado ao naufrágio, uma viagem em meio ao nevoeiro autoritário que perduraria até 1974 , totalizando 48 anos de despautérios políticos, sociais e econômicos.

Uma leitura cuidadosa d'As naus permite perceber a incidência constante da ideia de saudade, como se, aos retornados - tanto figuras grandiosas como a gente comum - do processo colonizatório falido, restasse apenas isto:

O marido olhou pela janela as lagunas de enguias de Bissau, o estuário deserto de pesqueiros, os telhados em que cantavam as guitarras sem cordas dos trovões, e viu reflectido um velho que demorou a reconhecer porque apenas se confrontava no espelho para a barba sumária dos sábados e prestava mais atenção aos lanhos do queixo que à calva, às rugas e outras marcas e devastações do tempo, esticando a pele de iguana do pescoço com os beliscos dos dedos. A crueldade dos anos magoou-o com um castigo injusto e ao voltar-se para encarar a mulher, sugando das gengivas uma remota saudade de chá, indignou-se a verificar, espantado, a erosão sem cura que o tempo provocara nela também, avariando-lhe as pernas de um mármore de varizes, aumentando-lhe as pálpebras, dissolvendo a cintura e admitiu com desgosto que Já não pertencemos nem sequer a nós, este país comeunos as gorduras e a carne sem piedade nem proveito uma vez que se achavam tão pobres como haviam chegado (...). Não somos parte alguma agora (LOBO ANTUNES, 2011, p. 38;40).

O trecho constitui rememoração de casal pobre e desabitado, vindo da Guiné Bissau. Aparecidos logo na quinta parte $^{1}$ do livro, marido e mulher envelhecidos funcionam como metonímias das pessoas comuns dentro do romance, encarnam o sofrimento vivido nas colônias, a carência de alternativa histórica, a saudade de um país que não chegou a existir, de fato, para todos os colonos que fizeram a vida na África Lusófona. Saudade perpetuada, pois segue insuperável também na metrópole desditosa, a Lixboa que congrega saudades de todos que a vem habitar, inclusive em atmosfera de sonho, de cariz esquizofrênico, sebastiânico para dizer tudo.

É impossível falar de velhos sôfregos, mas conscientes da decadência, sem mencionar o personagem clássico que se fixou no imaginário luso-brasileiro por sua consciência aguçada e contundência anti-épica, o velho do Restelo camoniano:

Mas um velho d'aspeito venerando, Que ficava nas praias, entre a gente, Postos em nós os olhos, meneando Três vezes a cabeça, descontente, A voz pesada um pouco alevantado, Que nós no mar ouvimos claramente, C'um saber só de experiências feito, Tais palavras tirou do experto peito:

- Ó glória de mandar! Ó vã cobiça Desta vaidade, a quem chamamos Fama!

Ó fraudulento gosto, que se atiça

C'uma aura popular, que honra se chama!

Que castigo tamanho e que justiça

Fazes no peito vão que muito te ama!

\footnotetext{
1 O romance não apresenta uma divisão clara em capítulos, como ocorre usualmente, pois não há numeração das partes (numeramos aqui para viabilizar consultas e referências), tampouco títulos. Tal fato denota um aspecto estilístico da obra, mas não só: remete ao desmantelamento do relato, em que a história de Portugal e suas antigas colônias não faz sentido, o que justifica a confusão cronológica de seus personagens, a aglomeração de vozes desterradas mescladas a do narrador e a propositadamente débil organização estrutural da narrativa.
} 
Que mortes, que perigos, que tormentas, Que crueldades neles experimentas!

(...) Chamam-te Fama e Glória soberana, Nomes com quem se o povo néscio engana.

- A que novos desastres determinas De levar estes reinos e esta gente? Que perigos, que mortes lhes destinas Debaixo dalgum nome preminente? Que promessas de reinos, e de minas D'ouro, que lhe farás tão facilmente? Que famas lhe prometerás? Que histórias? Que triunfos, que palmas, que vitórias? (CAMÕES, 1980, p. 271).

Nesta colagem, das estâncias 94 a 97 do canto IV, o eu poético-épico apresenta um personagem destoante do resto do livro. O ancião é desconfiado, despudorado, intrometido e consciente de algo que pouco importava no século XVI aos mandatários régios: o povo. Diz-se do velho do Restelo que é anti-épico. Como o casal idoso da Guiné-Bissau, o personagem profético está ciente de que o fim da expansão colonial repercutiria em miséria para as colônias, decadência para a metrópole e fragmentação identitária para as culturas envolvidas. Por isso, desentranha no canto anti-heroicizado uma vã cobiça, glória desigual, fama funesta, engodo para o "povo néscio", fonte de promessas e destinos falaciosos à gente corriqueira, esperançosa à beira-mar ou à beira-mágoa.

Em certo sentido, há muito em comum entre o velho d'Os lusíadas, o casal guineense d'As naus e o próprio narrador do romance: todos perfazem narrativas desconfiadas de uma glória que - vaticinaram - não chegaria para todos. Como veremos, a saudade, enquanto memória e, simultaneamente, aspiração do futuro, embotase com as previsões e/ou constatações pessimistas (porque realistas) dessas três vozes distintas que destacamos. A arte conserva mesmo estas contradições: descrê, mas escreve porque, minimamente, ainda se entende como espaço para realização daquilo que a história oficial não consolidou:

Os escândalos e excentricidades destroem a integridade épica e trágica do mundo, abrem uma brecha na ordem inabalável, normal ("agradável”) das coisas e acontecimentos humanos e livram o comportamento humano das normas e motivações que o predeterminam. (...) A "palavra inoportuna" é inoportuna por sua franqueza cínica ou pelo desmascaramento profanador do sagrado ou pela veemente violação da etiqueta (BAKHTIN, 2010, p. 134).

No excerto, Mikhail Bakhtin discute as origens do romance - o fim da integridade épica que estaria já presentada na sátira menipeia. $\mathrm{O}$ velho do Restelo, o narrador d'As naus e seus personagens que insistem: "eu não pertenço aqui" proferem a "palavra inoportuna", a franqueza incômoda no canto que se pretendia plenamente glorioso, pois se trata de um relato desarmônico em diferentes gêneros e em distintas épocas. No romance histórico, tal característica assume contornos ainda mais evidentes pelo esforço ético da forma literária:

Tudo isso está ligado ao caráter particular do romance, como destacamos no início: o fato de o conflito aparecer não "em si", mas em sua conexão objetiva e social, amplamente desdobrada, como parte de um grande desenvolvimento social. (...) O traço mais significativo dos romances realmente grandes consiste precisamente na figuração dessas orientações. O que é figurado não é determinado estado de coisas da sociedade, ou pelo menos um estado de coisas aparente. O mais importante é mostrar como a direção de uma tendência do desenvolvimento social se torna visível em movimentos (...) capilares da vida individual (LUKÁCS, 2011, p. 179-180).

A fala do teórico húngaro permite intuir que a "palavra inoportuna" de um velho e o resmungo tedioso de um casal africano são particularidades da vida cotidiana, mas não só: têm parte decisiva no "grande desenvolvimento social". É indiscutível, sob esta ótica, que o ancião do Restelo foge ao épico e indica direção decisiva para a literatura lusitana, pois ilustra uma tendência do desenvolvimento social que não podia passar despercebida em Camões no século XVI, muito menos no controverso e rico pendor crítico do romance histórico do fim do século XX.

Antes, contudo, de nos centrarmos nos momentos finais do século das guerras mundiais, importa visitar com atenção as suas primeiras décadas. Portugal - como o deflagra, na primeira metade do século XX, o vate lusitano, Fernando Pessoa - existe em função do sentimento de não se saber ao certo ser "vários" ou talvez "ninguém", conforme uma perspectiva garrettiana - traço identitário desdobrado em alteridade, ameaçada com o fim do mundo colonial. Ser metrópole e ser colônia; ser senhor e povo; ser autor e heterônimo, ser um e ser vários, como Pessoa e o próprio Portugal - um multiplicado em heterônimos, o outro esparramado entre pesadas heranças coloniais.

Como no romance de Lobo Antunes, também em Mensagem, de Pessoa, ainda na primeira parte do poema longo, denominada "Brasão", denuncia-se essa crise de pertencimento:

Não fui alguém. Minha alma estava estreita Entre tão grandes almas minhas pares,

Inutilmente eleita,

Virgemente parada; 
Porque é do português, pai de amplos mares, Querer, poder só isto:

O inteiro mar, ou a orla vã desfeita -

O todo, ou o seu nada

(PESSOA, 2011, p. 78).

Como os velhos da Guiné, que de lá saem em busca de uma realidade menos avariada em Lixboa, o eu poético da Mensagem, no poema acima, intitulado "D. João - Infante de Portugal" -, apresenta o sentimento de ausência de si mesmo - enquanto indivíduo, mas também enquanto comunidade-nação, "navio-nação" - no mundo. Ao português navegador dos séculos XV e XVI, a alma lusitana estreitava-se entre a metrópole esplendorosa e a rede colonial por fazer-se. Ser português era poder habitar, pelos amplos mares, todas as terras que estes lhes oferecessem. Na Lixboa deste tempo, revistada pelos ícones daquele tempo, a alma permanece confinada, agora entre a falência de uma metrópole desgastada aliada à incipiência das colônias martirizadas por séculos: a senhora proveniente da Guiné suga das gengivas uma remota saudade de chá, enquanto os personagens todos d'As naus sugam ao máximo uma saudade da existência portuguesa de outrora, cantada com a força vital da contradição, por Pessoa e Camões. Aliás, a própria Mensagem é o último aporte impossível da ambígua grandiloquência histórica lusitana, já encarando a "orla vã desfeita", que serve de palco à narrativa de Lobo Antunes.

Pois bem, falta indicar que as três obras possuem uma vinculação temática, mas, sobretudo, ética e estruturante. Embora a afirmação pareça forçosa - um poema (só) aparentemente ufanista; um romance quase niilista; um texto versificado nos moldes da alta tradição literária lusitana; uma obra em prosa que revela o apogeu da prosificação na escrita, tendo por base o popular, o vil e o ordinário -, não é custoso perceber que os três grandes motes da Mensagem ("Brasão", "Mar Português" e "O encoberto") estão, de alguma maneira, também presentes no naufrágio narrado pelo escritor contemporâneo. A primeira parte, Brasão, faz uma espécie de levantamento histórico do que conduziu à consolidação da nação portuguesa. A segunda exalta a expansão do reyno por meio dos portugueses conformadores da grande história colonial. A terceira seção, finalmente, prevê o duvidoso futuro lusitano, uma espécie de quinto império espiritual dialogando com a tradição sebastianista. Portando já alguma melancolia ou desconfiança histórica, referente, em simultâneo, ao passado e ao porvir.

A desconfiança histórica, intuída no canto IV lusíada, velada (mas presente) no nevoeiro da Mensagem, é nítida no romance analisado, pois, na medida em que o "encoberto" é posto a descoberto, liderando um grupo de ensandecidos, fica evidente que o futuro português é dúbio e inapreensível. Tanto quanto o presente: "Tudo é incerto e derradeiro. / tudo é disperso, nada é inteiro. / Ó Portugal, hoje és nevoeiro..." (PESSOA, 2010, p. 96).

O "Mar Português" também aparece notavelmente no texto em prosa: se Pessoa lembrava o movimento de partida dos heróis nautas cantados nos Lusíadas, Antunes destaca o percurso pelo mesmo mar, mas agora no caminho de volta, o do medíocre retorno. Os nativos defrontados com os colonizadores em terras africanas agora se reencontram com os senhores na antiga metrópole, para reconhecerem os decrépitos figurões históricos que outrora chegavam imponentes às novas terras. Os mesmos que, agora, juntam-se ao coro dos alcoólatras, desempregados, loucos e malfadados no centro de uma cidade com ares de pia mal lavada e mal-cheirosa:

(...) porque é que pelo simples desejo de ver o mar aceitei mudar-me para Lixboa e casar com um maluco de telefonias e sementes, quando o mar é apenas a selha desta água toda com as naus que tornam de África carregadas de colonos sem fortuna, de malucos que vendem as cinzas do pai como aquele cretino ali especado que nem maneiras tem, lambuza-se de gordura a comer, declama nos intervalos frases que se não entendem escritas num bloco de facturas, o mar, caneco, a porcaria do mar e esta cidade com odor de pia e de caliça (LOBO ANTUNES, 2011, p. 120).

A fala é, provavelmente, da "senhora do botânico" (idem, p. 119), mulher qualquer, desconhecida, que, no entanto, pensa - como o velho da praia nos Lusíadas ou o casal cansado da Guiné - e estabelece juízo nevrálgico sobre o cais em que foi parar. O cenário que o Camões escritor e histórico (não o personagem) pintou contrasta com o que agora se põe: "colonos sem fortuna, malucos que vendem as cinzas do pai", gente cansada da "porcaria do mar". Ao tocar no símbolo da cultura lusa, não se pode deixar de evocar o poema célebre do livro de 1934:
$\mathrm{X}$ - Mar Portuguez
Ó mar salgado, quanto do teu sal
São lágrimas de Portugal!
Por te cruzarmos, quantas mães choraram,
Quantos filhos em vão rezaram!
Quantas noivas ficaram por casar
Para que fosses nosso, ó mar!
Valeu a pena? Tudo vale a pena
Se a alma não é pequena.
Quem quer passar além do Bojador
Tem que passar além da dor.
Deus ao mar o perigo e o abysmo deu,
Mas nelle é que espelhou o céu
(PESSOA, 2010, p. 64) 
As divergências entre o mar português cantado no último fragmento destacado em prosa e este em verso é notável, mas há, ainda que menos evidentes, algumas semelhanças entre os dois textos. À primeira vista, o mar pessoano está muito mais filiado ao camoniano que ao "caneco" da prosa contemporânea - neste, o que se coloca em xeque é, justamente, as tantas lágrimas de Portugal que, parecem, persistir em verter já sem razão. "Mar Portuguez" e As naus fazem da cultura ultramarina tema, cenário, fundamento e mote para uma interrogação retrospectiva: "Valeu a pena?". No poema, o questionamento é seguido por célebre afirmação ufanista ("Tudo vale a pena/se a alma não é pequena"), mas não deixa de ser dúvida melancólica e desconfiada encrustada em escrito marco da alta tradição lusitana.

Em Lobo Antunes, diferentemente dos demais autores de sua geração ora citados, a exemplo de José Saramago, a pergunta "valeu a pena?" é respondida sempre negativamente. Não valeu, pois soa impossível cultivar, hoje, a alma vasta lusitana, depois do desmascaramento dos mitos consolidados, do estilhaço das alteridades construídas, bem como das crenças culturais e míticas cultivadas por séculos. As naus reencenam o descalabro histórico, figurando que a empreitada ultramarina não valeu a pena porque a alma de quem a realizou fora de uma pequenez insuportável. Disto, resultou o caos lixboeta, labirinto urbano e cultural no qual são apresentadas figuras reconhecidas da história, transformadas em inábeis, desnorteadas, em busca de nova inserção social num cenário pós-colonial. Conforme advertem as investigadoras portuguesas Margarida Ribeiro e Ana Paula Ferreira:

Contrariamente à historiografia, que, à sombra de vários regimes políticos, inclusive posteriores à descolonização, insiste em construir (e mobilizar) uma consciência de identidade colectiva modelada numa noção conservadora de continuidade histórica, As naus, de Lobo Antunes (...) exploram a descontinuidade narrativa, a contraposição de tempos anacrónicos, espaços e figuras históricas e fictícias, enfim a representação descentrada e paródica dos mitos colectivos da memória imperial, incluindo aqueles que sustentaram a guerra colonial e, posteriormente, as vicissitudes da descolonização (RIBEIRO; FERREIRA, 2003, p. 19-20).

A literatura, toda aquela que o seja de fato, escrevese para dizer que alguma coisa vale a pena. Por isso, em última instância, consideramos que o romance antoniano, ainda que pelas negativas, comporta alguma saudade que é memória para o futuro, revisão do passado e rejeição do presente. $\mathrm{O}$ descentralismo de sua narrativa aponta para possibilidades históricas e políticas igualmente descentradas, assim como a descontinuidade figural denota clamor necessário pela descontinuidade das mencionadas "vicissitudes" suportadas nos processos de colonização e descolonização.

A ideia de que o pranto das mães portuguesas, as preces vãs de seus filhos e o abandono das noivas à beira-mar constituem intuição de que Portugal ainda não passara de todo pelo Bojador - e, portanto, ainda convive com a dor - tem respaldo do importante crítico literário desse país, Eduardo Lourenço:

O Portugal de Pessoa, como história, política e cultura, também deixou de estar num tempo digno desse nome, mas [...] continua a percorrer os mares e os tempos que foram seus para atingir uma outra margem de que a história foi apenas antevisão, 'esgar e assombro'. É a mitologia portuguesa no seu conjunto - desde Ulisses a Viriato, de Nun'Álvares a D. Sebastião, de Bandarra a Vieira - que deve despertar da sua 'falsa morte', abandonar a sua pequena casa lusitana e fundir-se, como outrora o fizera em nome de um Cristo conquistador, travestido pelo fanatismo e pela ignorância, num império que não possa morrer, o da 'guerra sem guerra', onde conheceremos, enfim, o nosso verdadeiro nome (LOURENÇO, 1999, p. 74).

O pesquisador evoca as personas célebres que aparecem no Brasão (Ulisses, Viriato, Nun'Álvares e D. Sebastião) e no Encoberto (D. Sebastião novamente, Bandarra e Vieira) para dizer que o eu lírico da Mensagem os ressuscita a fim de que a memória desses possa revigorar Portugal, ainda deveras impressionado com a sua "pequena casa lusitana", em verdade, somente quintal da Europa. O rosto que outrora fitava o mar, agora fita o nevoeiro. Da estirpe de pensadores da questão nacional em Portugal, Eduardo Lourenço (aliado a Agostinho da Silva, Teixeira de Pascoaes, Antonio Quadros e o próprio Fernando Pessoa) vê na investida pessoana, mesmo que recoberta de impreciso ufanismo, uma convocação à guerra intelectual pela identidade portuguesa, pelo "nosso verdadeiro nome". $\mathrm{O}$ apelo às Cruzadas ("travestido pelo fanatismo e pela ignorância") resiste para dizer que o império não pode morrer - não no plano da cultura - e que, depois do nevoeiro autoritário, a nação polifônica precisa existir para todos os seus filhos em preces, mães chorosas e noivas por-casar.

Como o pensador referido resgata a mitologia portuguesa para chegar ao entendimento de que é preciso despertá-la de sua "falsa morte", cabe deixarmos momentaneamente em suspenso o percurso crítico pelas Naus em preferência a uma análise pouco mais detalhada do poema ortônimo: 


\section{PRIMEIRO \\ ULYSSES}

O mytho é o nada que é tudo.

O mesmo sol que abre os céus

É um mytho brilhante e mudo -

O corpo morto de Deus,

Vivo e desnudo.

Este, que aqui aportou,

Foi por não ser existindo.

Sem existir nos bastou.

Por não ter vindo foi vindo

E nos creou.

Assim a lenda se escorre

A entrar na realidade,

E a fecundal-a decorre.

Em baixo, a vida, metade

De nada, morre (PESSOA, 2010, p. 19).

O poema integra a seção primeira do livro intitulada, como se disse, "Brasão". Não poderia ser diferente: os versos componentes de Ulysses fazem a justificação da cultura portuguesa, isto é, muito mais que a imagem de um brasão formulada a partir do catolicismo e dos reinados, o que vivifica essa nação é a unidade do mito, de um passado que reverbera no presente e no futuro. Para aclarar tal concepção, importa rememorar o crítico estado-unidense Northrop Frye, que, em seu livro Fábula de identidade: ensaios sobre mitopoética, debruça-se sobre a questão:

O mito, portanto, fornece os principais contornos e a circunferência de um universo verbal que é mais tarde também ocupado pela literatura. A literatura é mais flexível do que o mito e preenche esse universo de modo mais completo: um poeta ou romancista pode trabalhar em áreas da vida humana aparentemente distantes dos deuses vagos e dos deuses narrativos gigantescos da mitologia. Mas em todas as culturas, a mitologia se funde imperceptivelmente na e com a literatura (...). Em primeiro lugar, mitologia, como estrutura total, que define as crenças religiosas, as tradições históricas e as especulações cosmológicas de uma sociedade - em resumo, a extensão inteira de sua expressividade verbal -, é a matriz da literatura; a poesia maior fica retornando a ela. Em cada época, poetas que são pensadores (...) e que estão profundamente preocupados com a origem, o destino ou os desejos da humanidade - com qualquer coisa que pertença aos contornos mais amplos daquilo que a literatura pode expressar - dificilmente conseguem achar um tema literário que não coincida com um mito (FRYE, 2000, p. 41).

O mito é fundamento na épica camoniana, esclarecimento histórico e mito-poético emprestado no poema pessoano e retrato do abismo entre histórico e existencial na prosa de Lobo Antunes. Vale entender melhor a presença mítica em cada uma das obras supracitadas, ainda que seja impossível, nesta incursão breve, dar conta disso em toda sua amplitude e complexidade. Frye não trata diretamente da tríade que aqui perscrutamos, mas deixa pistas que nos podem ser úteis. Em sua concepção, toda grande literatura retorna ao mito porque ele está diretamente vinculado ao destino humano, enquanto aspiração de realização de nossa humanidade. Na epopeia seiscentista não seria diferente:

Canto X - Estância 10

Cantava a bela Deusa que viriam Do Tejo, pelo mar que o Gama abrira, Armadas que as ribeiras venceriam Por onde o Oceano Índico suspira; E que os gentios reis que não dariam A cerviz sua ao jugo, o ferro e ira Provariam do braço duro e forte, Até render-se a ele ou logo à morte (CAMÕES, 1980, p. 313).

Camões, em função da condição temporal em que se situa dentro da história da literatura, consegue reunir em sua obra bibliomaníaca mitos inerentes à cultura clássica e à religião moderna do período, o cristianismo, sem falar nas raízes populares de sua lavra. Deuses pagãos vêm dizer aos portugueses cristãos que a sua Glória é certa - o que vaticina, a um só tempo, o sucesso de Vasco da Gama com a proteção de todos os deuses possíveis e a boa-aventurança do próprio Camões, leitor-autor da tradição mítica greco-romana em mescla oportuna com a tradição cristã moderna (ascendente porque igualmente expansionista e conquistadora). A bela deusa grega confere ao navegante ocidental o prenúncio de que, abertas as portas do mar através de um rio chamado Tejo, toda a terra conquistada estaria sob o jugo do poder terreno lusitano.

Sob este "nada que é tudo", consolida-se uma nação por onde escorre/circula a lenda, a entrar na realidade e a fecundá-la. O mar é o grande mito que percorre as três obras revisitadas aqui - mar enquanto caminho, itinerário histórico e metafórico, legado pela divindade aos homens de um pequeno país na Ibéria. Quase quatro séculos depois, como que a invocar o velho pacto estabelecido entre os deuses e os navegantes, o eu poético pessoano pergunta:
O encoberto - Os avisos - TERCEIRO
'Screvo meu livro à beira-mágoa.
Meu coração não tem que ter.
Tenho meus olhos quentes de água.
Só tu, Senhor, me dás viver.
Só te sentir e te pensar
Meus dias vácuos enche e doura. 
Mas quando quererás voltar?

Quando é o Rei? Quando é a Hora?

(...) Quando virás, ó Encoberto,

Sonho das eras português,

Tornar-me mais que o sopro incerto

De um grande anseio que Deus fez?

Ah, quando quererás voltando,

Fazer minha esperança amor?

Da névoa e da saudade quando?

Quando, meu Sonho e meu Senhor?

(PESSOA, 2010, p. 85).

O primeiro verso encaminha o tom em que se inscreve o poema: não mais à beira-mar, como o poeta que cantou os navegantes partindo (ficando, em terra, apenas o velho do Restelo a defender as viúvas, órfãos e demais pessoas comuns), mas à beira-mágoa. Persiste a sombra do mito, com evocações constantes ao Deus cristão, agora, porém com perguntas sem respostas convincentes - não com certezas de seu braço "duro e forte" a defender os homens dos mares: mas quando quererás voltar?/ Quando é a Hora? De Camões a Lobo Antunes, passando por Pessoa, a resposta continua oblíqua e problemática.

Toda a Mensagem parece escrever-se sob a égide dessa interrogação: quando chegará a Hora do fim do nevoeiro. Ou pior: o Encoberto, sonho das eras português, um dia chegará a ser mais que sopro incerto? Nesta toada, já se verifica, em princípios do século dos extremos (para ficar com expressão de Erich Hobsbawm), pelo épico pessoano desassossegado, uma consciência despertada da especificidade colonizadora portuguesa. Consciência de uma valoração excessiva do mito que chega ao ápice na narrativa de fins do mesmo século, quando roubam a cena as atrocidades do processo de descolonização em África. Sobre essa concepção imperial portuguesa, contribui significativamente a historiadora Margarida C. Ribeiro:

\begin{abstract}
Não há dúvida que todo o ideário de pioneirismo dos Descobrimentos portugueses e de cruzada acrescentava à posição portuguesa o peso religioso, histórico e moral que o regime transformou e sagrou para "imobilizar" o imaginário da nação no seu singularismo e excepcionalidade antiquíssima. E é este aspecto que se articula com o que de facto distingue esta guerra das outras guerras coloniais e que tem a sua raiz na especificidade da concepção imperial portuguesa - a ligação orgânica entre a ideia colonial e a identidade nacional - e portanto o reforço da ideia, que percorreu todas as ideologias imperialistas e colonialistas dos séculos XIX e XX (...) de que Portugal sem colónias deixaria de existir (RIBEIRO, 2004, p. 189).
\end{abstract}

Fazendo revisão da história colonial portuguesa à luz dos estudos pós-coloniais em seu Uma história de regressos (2004), Ribeiro indica que a empreitada colonizadora significou para os lusitanos, desde o momento inicial, com Camões, uma especificidade identitária, posto que o ser português filiou-se, mítica e politicamente, à noção de ser império, metrópole, "pai de amplos mares". A investigadora destaca o uso oportunista, no regime salazarista, deste imaginário nacional para justificar as guerras cruentas em antigas possessões africanas. Pessoa, em 1934, publica Mensagem que, ao contrário do que defendeu uma primeira crítica nacionalista, ecoa antes um canto fúnebre representativo desta consciência do desgaste e mácula do mito que uma canção ufanista em salvaguarda do ideal imperialista. Seguramente, a prosa antoniana da última metade do século lança no sanatório todos aqueles que insistem em crer, às portas do novo milênio, que a Portugal cumpria sustentar colônias em regimes socioeconômicos decadentes, para que se garantisse a subsistência da própria identidade lusa.

O eu poético terceiro dos Avisos não é nomeado, como os antecedentes, Bandarra e Vieira, justamente por lançar a intuição de ser o próprio Pessoa, em ação literária e política inquietante, por significar distanciamento proposital da sombra de Camões. Este inominado vai-se saturando ao longo do poema porque chega a não ter mais nada que fazer além de questionar, retoricamente talvez. Um leitor atencioso de toda a seção intitulada "Encoberto" perceberá que, nos Avisos anteriores, de Bandarra e Vieira, não há uma interrogação sequer. São poemas concisos e conscientes de que Portugal é a consolidação do Quinto Império. O terceiro aviso, que já frisamos sem atribuição autoral explícita, é duvidoso, com uma confissão final: quando, até quando, o mito servirá para perpetuar névoa e saudade? As naus respondem:

- D. Sebastião aparece das ondas num cavalo branco (...). Amparados uns aos outros para partilharem em conjunto do aparecimento do rei a cavalo, com cicatrizes de cutiladas nos ombros e no ventre, sentaram-se nos barcos de casco ao léu, no convés de varandas das traineiras, nos flutuadores de cortiça e nos caixotes esquecidos (...). Esperámos (...) um adolescente loiro, de coroa na cabeça e beições amuados, vindo de Alcácer Quibir com pulseiras de cobre trabalhado dos ciganos de Carcavelos e colares baratos de Tânger ao pescoço, e tudo o que pudemos observar, enquanto apertávamos os termómetros nos sovacos e cuspíamos obedientemente o nosso sangue nos tubos do hospital, foi o oceano vazio até à linha do horizonte coberta a espaços de uma crosta de vinagreiras, famílias de veraneantes tardios acampados na praia, e os metres de pesca, de calças enroladas, que olhavam sem entender o nosso bando de gaivotas em roupão, empoleiradas a tossir nos lemes e nas hélices, aguardando, ao som de uma flauta que as vísceras do mar emudeciam, os relinchos de um cavalo impossível (LOBO ANTUNES, 2011, p. 176-182). 
O fim do romance é desconcertante e revelador de um presente histórico insano e desencontrado: a cena transcrita, numa estratégia de bricolagem, articula momentos díspares da parte derradeira do livro, em que o governo português deposita "os colonos que vagavam à deriva" (LOBO ANTUNES, 2011, p. 173) num antigo hospital de tuberculosos, sem sequer retirar de lá os funcionários responsáveis pelos doentes, que, na falta dos enfermos anteriores, seguem dando o mesmo tratamento de sanatório aos desnorteados Luís de Camões, Vasco da Gama dentre outros colonizadores anacrônicos e ainda assim ilustres, apesar de tudo. Um conjunto de velhos barões assinalados agora cicatrizados, assentados em caixotes esquecidos no convés, aguardam, com a ansiedade de uns quinhentos anos, o aparecimento de um menino angélico e andrógeno ou, mais que isso, messiânico, para salvar Portugal de um oceano vazio para-além do horizonte. Juntamente aos pescadores, de calças enroladas, e aos transeuntes comuns, os ex-colonos e ex-conquistadores amalucados, incompatíveis com um mundo sem ninfas ou sereias, apreciam o decadente espetáculo da chegada impossível de um rei imaginário e já muito literário na contemporaneidade.

É o fim do mito, mas, como Frye destaca, este não deixa de se fazer presente - mesmo quando sua existência torna-se imponderável. O narrador estabelece, ao longo de todo o romance, um jogo paródico e irônico para, ao final do enredo, pintar um cenário tão imaginativo quanto as demais obras literárias aqui mencionadas, com a ressalva de ser agora também e contrastivamente melancólico - o destino de Portugal não se cumpriu. À pergunta pessoana da primeira metade do século XX - "Quando virás, ó Encoberto?" - responde-nos o prosador do final da mesma centúria: nunca.

A cultura portuguesa, desdobrada em literatura, soube, ao longo dos anos de espera, arquitetar uma alternativa genuína para a superação do "não" apontado em As naus. Pela ferramenta psíquica e estilística da saudade, a história lusa se organiza e à literatura cabe fazer deste artifício um perscrutar recorrente pela plenitude:

A saudade inclui a esperança; e por isso, a lembrança visa também o futuro. Estas duas forças (uma criadora e outra perpetuadora) são a essência e o corpo da Saudade. Várias vezes aludimos a este facto que nos deixa pressentir o sentido da nossa Elegia nevoenta e misteriosa, como a ilha do Encoberto. Sendo a Saudade uma força criadora (esperança) e perpetuadora (lembrança), a Saudade é a própria Natureza afeiçoada ao sentimento lusitano (...). A tristeza lusíada, nascida do sangue e da terra, tem um relevo espectral e plástico, iluminado e nevoento (...). A tristeza lusíada não é mais que o vestuário da Saudade (PASCOAES, 1987, p. 160-164).
O importante poeta e teorizador do saudosismo, Teixeira de Pascoaes, reveste a tradição portuguesa de uma tristeza que não o é propriamente, mas sim saudade, enquanto sentimento, mas, sobretudo, como ação tríplice: lembrar, criar e perpetuar. A saudade, neste contexto, reconfigura o mito e passa a ser entendida como força criativa que dá sentido à "Elegia nevoenta e misteriosa", como se esta pressentisse um Quinto Império - na nossa percepção, menos localista, nacionalista e, certamente, mais polifônico, porque mais cultural e comunitário que econômico e político.

A literatura insiste em indicar algo para-além do nevoeiro, por isso vincula-se tanto à noção de saudade. $\mathrm{O}$ romance em questão traveste-se de destino, para dizer que tal desdita pode ser driblada. Assim, vamos ladeando a teorização de György Lukács sobre o romance histórico, em que o mais decisivo parece ser recontar o presente sem perder de vista uma aspiração saudosa do futuro, visto que o passado é a pré-história do presente, que já é futuro:

As crises históricas figuradas são componentes imediatos dos destinos individuais das personagens principais e constituem, assim, parte orgânica da própria ação. Desse modo, os elementos individual e sócio histórico estão inseparavelmente ligados um ao outro tanto na caracterização quanto na condução do enredo (LUKÁCS, 2011, p. 246).

O que ocorre com o romance português contemporâneo de grande envergadura estética e histórica - de que As naus constituem exemplo - é uma profunda perspicácia no trabalho de imiscuir as grandes crises históricas nacionais às contendas do realismo moderno (para pensar com Erich Auerbach, 2011). A vida do icônico Luís de Camões atrela-se, a um só tempo, à orfandade portuguesa depois das guerras coloniais e o fim do império mais sonhado que realizado, bem como ao alcoolismo de um homem comum. Pedro Álvares Cabral é o mandatário de uma frota marítima vindoura, mas convive com a prostituição feminina do baixo corporal geralmente associado à literatura prosaica e popular. D. Manuel é rei, dono desta "bodega toda" (LOBO ANTUNES, 2011, p. 142), entretanto é também pueril, imaturo, frágil: "o que se passa é que senti tua falta" - diz ao companheiro de cartas, Vasco da Gama, outro manequim de conquistador em tempos supostamente pós-modernos.

Neste sentido, a literatura, em seu grande tempo perpetuamente respondível, persiste revelando a humanidade do homem, conferindo, aos grandes e aos pequenos da história, a sensibilidade cotidiana para lhes tornar humanos; aos pequeninos do mundo vil, a grandeza da matéria literária. Em síntese, somente a 
ação humana - a do homem chamado Luís de continuar escrevendo, a do casal da Guiné enfrentando um trajeto marítimo histórico e decadente para perguntar em Lixboa o que será desses despregados do mundo, a ação dos conquistadores arlequim de fazer de "tudo na vida, desde descobrir a Índia e limpar, com as próprias mãos, as diarreias e os vómitos de meu irmão moribundo Paulo da Gama (IDEM, p. 135) - pode atribuir sentido ao destino aparentemente implacável do realismo ordinário. Como afirma o pensador húngaro:

a questão da ação é, pois, o núcleo dos problemas formais do romance (...). A configuração da ação é o único caminho se trata-se de dar forma à relação concreta do homem com a sociedade e com a natureza (LUKÁCS, 2011, p. 40).

O mesmo que conclusivamente completa: "só a práxis humana pode expressar concretamente a essência do homem" (LUKÁCS, 2010, p. 161).

É tempo de voltar à Mensagem - com toda a sua reminiscência camoniana - para findarmos nosso comparatismo:

\section{TORMENTA}

Que jaz no abysmo sob o mar que se ergue

Nós, Portugal, o poder ser.

Que inquietação do fundo nos soergue?

$\mathrm{O}$ desejar poder querer

(PESSOA, 2010, p. 92)

Do mesmo mar que os colonos do sanatório aguardam a irrupção do rei mítico, erige a solução pessoana que - apartadas as possíveis interpretações ufanistas, coniventes ao período salazarista de publicação do poema, mas inadequadas à nossa análise crítica - emoldura toda a literatura historicamente consciente e esteticamente acertada: o mar de "Tormenta" deixa escapar, ainda que de maneira velada, o "poder ser". Soergue inquieto o "desejar poder querer". A mesma saudade produtiva de que tratava Pascoaes, a mesma práxis humana voltada para a realização do ser social em plenitude, pelo qual clamava Lukács, especialmente depois da "virada ontológica".

"Todo cais é uma saudade de pedra" (CAMPOS [PESSOA], 2007, p. 103) e toda poética portuguesa, em verso e prosa, é a literatura nauta de uma viagem sem volta, mas com alguma expectativa de futuro, se não redentor, ao menos inquiridor. De Camões, passando por António Vieira, Almeida Garrett, Teixeira de Pascoaes e Fernando Pessoa até chegar a António Lobo Antunes, todos revelam a vida inundada de impossibilidades, mas com a saudade futura de que a arte (ainda, desde os idos de 1500) pode melhor os homens ou, minimamente, pode incutir-nos a consciência de que "pertencemos aqui".

O império colonial é um fardo lusitano legado à ex-metrópole e às ex-colônias, embora tais atores históricos envolvidos tenham procurado redimensionar seus projetos de pertencimento identitário, como países independentes. As naus, romance prosaico do nosso tempo, reencenam uma relevante memória literária e histórica para figurar as (im)possibilidades de cumprimento de certo "Portugal como destino", no que se refere às categorias de povo, identidade $\mathrm{e}$ cultura, embora haja uma tradição representada de modo pleno no plano artístico. A referida obra de Lobo Antunes aponta, em meio ao desmantelamento formal da narrativa e ao desmonte da sociedade imperial de antanho, para um "querer ser" outro país, tendo em conta uma nova dimensão de futuro - uma semelhante consciência problematizante encontrada no eu-poético de Mensagem - como alternativa presumível e viável para uma nação agora de destino pós-colonial, livre definitivamente de quaisquer líderes salvadores e de um tempo histórico como pesadelo, ancorada desta feita transgressivamente na verve criadora de mundos poéticos libertos (utópicos ou distópicos) de ameaçadores nevoeiros do passado, como propõe a geração literária de António Lobo Antunes.

\section{Referências}

AUERBACH, Erich. Mimesis: a representação da realidade na literatura ocidental. Vários tradutores. 5. ed. São Paulo: Perspectiva, 2011.

BAKHTIN, Mikhail. Problemas da poética de Dostoievski. 5. ed. Trad. Paulo Bezerra. Rio de Janeiro: Forense Universitária, 2010.

CAMÕES, Luís de. Os lusíadas - Vocabulários I. 2. ed. Rio de Janeiro: Presença; Brasília: Instituto Nacional do Livro III, 1980 .

FRYE, Northrop. Fábulas de identidade: ensaios sobre mitopoética. Trad. Sandra Vasconcelos. São Paulo: Nova Alexandria, 2000.

HOBSBAWM, Eric. Era dos extremos: o breve século XX: 1914-1991. Trad. Marcos Santarrita. São Paulo: Companhia das Letras, 2008.

LOBO ANTUNES, António. As naus. Rio de Janeiro: Objetiva, 2011.

LOURENÇO, Eduardo. Portugal como Destino seguido de Mitologia da Saudade. Lisboa: Gradiva, 1999.

LUKÁCS, György. Narrar ou descrever? Uma discussão sobre naturalismo e formalismo. Marxismo e teoria da literatura. Tradução de Carlos Nelson Coutinho. 2. ed. São Paulo: Expressão Popular, 2010, p. 149-185.

O romance histórico. Tradução de Rubens Enderle. São Paulo: Boitempo, 2011. 
PASCOAES, Teixeira de. Os poetas lusíadas. Lisboa: Assírio \& Alvim, 1987.

PESSOA, Fernando. Poesia completa de Álvaro de Campos. São Paulo: Companhia das Letras, 2007.

. Mensagem. Edição clonada do original da Biblioteca Nacional de Portugal. Lisboa: Babel, 2010.

RIBEIRO; Margarida Calafate; FERREIRA, Ana Paula. Apresentação. (Org.). Fantasmas e fantasias imperiais no imaginário português contemporâneo. Porto: Campo das Letras, 2003, p. 9-28.
RIBEIRO, Margarida Calafate. Uma história de regressos: Império, Guerra Colonial e Pós-Colonialismo. Porto: Afrontamento, 2004.

Recebido: 30 de abril de 2016 Aprovado: 25 de setembro de 2017 Contato: edvaldobergamo@gmail.com (Edvaldo A. Bergamo) ana.medeiros@ifg.edu.br (Ana Clara Magalhães de Medeiros) 